\title{
SATISFACTION AND COMPARISON INCOME
}

\author{
Andrew E. Clark \\ (DELTA (Joint Research Unit CNRS-EHESS-ENS), Paris) \\ Andrew J. Oswald* \\ (Centre for Economic Performance, London School of Economics)
}

Revised: August 1995

\begin{abstract}
$\underline{\text { ABSTRACT }}$
This paper is an attempt to test the hypothesis that utility depends on income relative to a 'comparison' or reference level. Using data on 5,000 British workers, it provides two findings. First, workers' reported satisfaction levels are shown to be inversely related to their comparison wage rates. Second, holding income constant, satisfaction levels are shown to be strongly declining in the level of education. More generally, the paper tries to help begin the task of constructing an economics of job satisfaction.

JEL Classification Code: C25, D00, J28.

Keywords: Job Satisfaction, Relative Utility, Comparison Income, Education, Empirical Estimation.
\end{abstract}

Correspondence to: Andrew Oswald, Centre for Economic Performance, London School of Economics, Houghton Street, London, WC2A 2AE. Telephone: 0171-955-7284. Fax: 0171-9557595. 


\section{$\underline{\text { SATISFACTION AND COMPARISON INCOME }}$}

\section{1. $\quad$ Introduction}

One of the most interesting ideas in social science is the notion that happiness depends upon relative income. Although the terminology varies across disciplines, a common theme in the psychology, sociology and administrative science literatures is the concept of a reference level of income against which an individual compares himself or herself. When that individual's earnings fall relative to the comparison level, he or she feels relatively deprived, and is less happy.

Relative deprivation theory has not made substantial inroads into the economics literature. This is presumably because economists believe that utility depends on absolute income alone. The theory has, however, generated a small number of papers and books. Writers like Easterlin (1974), Boskin and Sheshinski (1978), Layard (1980), Frank (1985) and Akerlof and Yellen (1990) argue that many of the most conventional ideas about economic policy would be overturned in an economy where relative income matters. ${ }^{1}$ Nevertheless, the lack of empirical evidence, except of what most economists view as of a circumstantial nature ${ }^{2}$, has kept relative deprivation $^{3}$ theory on the periphery of research in economics.

The purpose of this paper is to provide a test of the theory that happiness depends upon a comparison level of income. It does so by using new data on a random sample of workers who are asked how content they feel with their jobs. The data set thus provides self-reported levels of satisfaction. Such data are rarely used by economists, but form the basis for a large empirical literature in social psychology. ${ }^{4}$ The paper combines these satisfaction statistics with data on comparison incomes calculated using an earnings model that is conventional in economics but is apparently unknown in the psychology literature.

A more general aim of the paper is to explore the patterns in job satisfaction data. 
Relative to its importance, the economics literature on workers' well-being is small. The paper attempts to further this analysis.

The first finding of the paper is that workers' reported levels of well-being are at best weakly correlated with absolute income alone. Its second, and central, finding is that measures of comparison income are significantly negatively correlated with reported levels of happiness at work. The third finding is that the higher the level of education, the lower the reported satisfaction level. This is harder to interpret, but may be consistent with the view that utility depends on the gap between outcomes and aspirations, and that education raises aspiration targets.

Section 2 discusses the main ideas of, and historical background to, relative deprivation theory. Sections 3 and 4 estimate satisfaction equations. Section 5 concludes.

\section{2. $\quad$ Relative Deprivation and Comparison Income}

Define an individual's utility from working as either

$$
\mathrm{u}=\mathrm{u}(\mathrm{y}, \mathrm{h}, \underline{\mathrm{i}}, \mathrm{j}),
$$

where $\mathrm{y}$ is income, $\mathrm{h}$ is hours of work, and $\underline{\mathrm{i}}$ and $\mathrm{j}$ are sets of individual and job parameters respectively, or as

$$
\mathrm{u}=\mathrm{u}\left(\mathrm{y}, \mathrm{y}^{*}, \mathrm{~h}, \underline{\mathrm{i}}, \mathrm{j}\right)
$$

where $\mathrm{y}^{*}$ is a comparison or reference income level against which the individual compares himself or herself. Equation (1) is the standard economists' model, found in every microeconomics textbook. Assume, as conventional, that utility is increasing in income, $\mathrm{y}$, and decreasing in hours worked, h. Equation (2), which is closer to the theoretical models found in social psychology textbooks, assumes that utility is declining in the comparison pay level, $\mathrm{y}^{*}$. This captures an effect that can be described as relative deprivation, envy, jealousy or inequity.

Versions of equation (2) abound in social science literatures other than economics. 
Adams' $(1963,1965)$ equity theory is one prominent example; another is Runciman (1966); a third is Homans (1961). ${ }^{5}$ Economists who have written down models like equation (2) include Akerlof and Yellen (1990), Baxter (1988), Boskin and Sheshinski (1978), Duesenberry (1949), Gylfason and Lindbeck (1984), Hochman and Rogers (1969), Frank (1984a,b, 1985), Johansen and Strøm (1994), Kapteyn and Van Herwaarden (1980), Ireland (1994), Lommerud (1989), Nickell and Andrews (1983), Oswald (1979, 1983), Pencavel (1991), Solow (1990), Scitovsky (1976), Trevithick (1976), Van de Stadt et al (1985), Veblen (1949), and Wood (1978). ${ }^{6}$ These are greatly outweighed, however, by the conventional literature based on equation (1).

A closely related economics literature is concerned with "fairness". Survey evidence such as Kahneman, Knetsch and Thaler (1986) shows that people have strong views about fairness in economic exchange. Laboratory evidence on so-called ultimatum games (Guth et al, 1982, Bolton, 1991, and Smith, 1994) suggests that individuals will throw away real income to obtain a fairer division of a smaller pie. It seems likely that decisions about fairness rest on some sort of comparative process, but the details are not well understood.

The form of test undertaken here is a simple and, in retrospect, natural one. The paper uses a microeconomic data set on individuals who report their levels of satisfaction, pay and hours of work. It calculates their 'comparison' income levels using a standard form of Mincer earnings equation. This equation provides a predicted or expected wage that is taken as a proxy for comparison income. Alternatively, an individual's peers' wage might simply be measured. This paper uses both methods.

One nested test, designed to discriminate between equations (1) and (2), is therefore to estimate directly a regression equation for equation (2). The t-statistic on this variable $\mathrm{y}^{*}$ then tests the null hypothesis that the conventional equation (1) is the correct specification of the utility function. It might be argued that equation (2) would not revolutionize economics research 
because it merely makes explicit a variable implicit, or held constant, in equation (1). On this view, the results described later in the paper do not pose a threat to conventional economic theory, but rather add empirical detail to the structure of 'tastes'. There is something to this, but it misses the fact that a concern for relativities leads to different behavioural implications, and different policy prescriptions, than those from conventional models.

A precursor to this paper is an original but comparatively little-known paper by Hamermesh (1977). The author takes a sample of American employees, covering the years 1969 and 1973, and estimates job satisfaction equations. This seems to be the earliest article of its kind in the economics literature. Although Hamermesh's focus is upon occupational choice and the effects of training, and he does not discuss - at least in any detail - ideas of relative deprivation, his regression equations include the residual from a wage equation as an explanatory variable. ${ }^{7}$ That residual enters positively and significantly in a job satisfaction regression, which is akin to finding that $y-y^{*}$, in the earlier notation, affects utility. More recently, Lévy-Garboua and Montmarquette (1994) and Sloane and Williams (1994), using Canadian and British data respectively, have examined the correlation between predicted income and job satisfaction. Watson et al (1992) is in the same tradition.

A recent study of satisfaction has been undertaken by Cappelli and Sherer (1988). They use data on approximately 600 employees working for a major US airline. Regression equations (using OLS) are estimated for satisfaction with pay and satisfaction with work. An outside "market wage", calculated by averaging pay for specific occupations in other airlines, is statistically significant and negative in one of the two equations reported for pay satisfaction. Moreover, it is fairly close to being of equal size but opposite in sign to the coefficient on a variable for the actual wage earned by the worker. Thus the specification is close to a pure relative wage effect. For the regression results on work satisfaction, market wages are 
insignificant, and change sign across different regressions. In a related paper, Cappelli and Chauvin (1991) show that relative wages help to predict actions as well as attitudes. Disciplinary layoffs in a large manufacturing company are negatively and significantly related to a plant's wage premium.

The appropriate interpretation of union variables has been the central concern of the small economics literature on job satisfaction. Borjas (1979) draws on a sample of men from the 1971 National Longitudinal Survey of Mature Men. His main conclusion is that being a trade union member has a large and significant negative effect on reported job satisfaction. This effect has also been found by Freeman (1978), who uses data from the US PSID and NLS, and, more recently, by Blanchflower and Oswald (1992), Clark (1996), Meng (1990) and Miller (1990). Other research has considered the link between job satisfaction and age (Clark, Oswald and Warr, 1995), gender (Clark, 1995b), race (Bartel, 1981) and the size of the establishment (Idson, 1990).

\section{Empirical Results on Satisfaction and Comparison Income}

The data in this paper come from wave 1 of a random sample of approximately 10,000 individuals in approximately 5,500 British households. The data were collected in late 1991. This data set, the British Household Panel Study (BHPS), includes detailed information on job satisfaction. All working respondents were asked to rate their satisfaction levels with seven items: promotion prospects, total pay, relations with supervisors, job security, ability to work on their own initiative, the actual work itself, and the hours of work. Each of these was to be given by the worker a number from one to seven, where one corresponded to "not satisfied at all", seven corresponded to "completely satisfied", and the integers from two to six represented intermediate levels of satisfaction. Individuals were then asked a final question, after they had rated their levels of contentment with the list of topics, worded as:

"All things considered, how satisfied or dissatisfied are you with your present job overall 
using the same 1-7 scale?"

These answers form the basis for most of the later empirical work in the paper. The data on satisfaction with pay are used as a check on a particular hypothesis, but the main empirical analysis concerns the determinants of overall job satisfaction. The way the question was asked suggests that individuals' replies weigh up many attributes of the job package. ${ }^{8}$ Hence the data may approximate total well-being from work rather better than can a narrow question about job satisfaction.

This paper treats people's reported satisfaction levels as proxy utility data. ${ }^{9}$ Because there is almost no economics literature using such an approach, some economists are likely to worry about the credibility and robustness of an analysis that draws upon reported numbers on satisfaction. Perhaps the best defence against concern of this sort is to point to the very different attitude taken by researchers in the psychology literature. Psychologists, no less than economists, are interested in data that contain reliable information about human behaviour. The huge literature on job satisfaction in psychology journals - though different in emphasis from the empirical results given later in the paper - is a testament to the seriousness with which research psychologists treat survey responses on feelings of well-being. As psychologists are likely to be more skilled than economists at judging the quality of such data, this might be thought sufficient grounds for economists to use statistics on satisfaction. More explicitly, however, the justification for studying subjective assessments of satisfaction is that they are correlated with observable events and actions. For example, there are strong correlations, in the expected direction, between job satisfaction and the following:

(i) Poor mental health

(ii) Length of life

(iii) Coronary heart disease
Wall, Clegg and Jackson (1978)

Palmore (1969)

Sales and House (1971) 
(iv) Labour turnover

(v) Absenteeism

(vi) Counter- and non-productive work
Freeman (1978), McEvoy and Cascio (1985),

Akerlof, Rose and Yellen (1988)

Clegg (1983)

Mangione and Quinn (1975)

Further evidence can be found in Bradburn and Noll (1969), Locke (1976) and Long et al (1982). Bradburn and Caplovitz (1965) also show that there is reason to believe that individuals' selfevaluations are consistent through time. Thus satisfaction data are not merely random numbers (though they will be measured with error).

To encourage intuition, consider an individual enjoying 'total' utility v. Write this utility function, which psychologists might term a 'life satisfaction' function, as

$$
v=v(u(y, h, \underline{i}, j), \mu) .
$$

Where $\mathrm{u}$ is utility from work and $\mu$ is utility from other sources and spheres of life. Therefore $u($. is a kind of sub-utility function capturing the level of well-being that the person receives from all aspects of his or her job. Utility from working depends on the income earned from the job, the number of hours worked, and vectors of person-specific and job-specific characteristics. The other component of utility, $\mu$, may be determined quite differently, and can be expected to depend on factors such as the quality of family life, friendships, the individual's health, and many personal variables outside the realm of the economist. Assuming that life utility, $\mathrm{v}$, is increasing in both its arguments, economists would ideally like data on $\mathrm{u}$, the utility associated with work. The job satisfaction data used in this paper, which come as summary measures after the series of questions asking individuals to consider many particular attributes of the work, may be thought of as statistics on $\mathrm{u}(\mathrm{y}, \mathrm{h}, \underline{\mathrm{i}}, \mathrm{j})$. These data, like most data studied by economists, are highly imperfect representations of the underlying theoretical ideal. They are grouped into several bands, are qualitative orderings rather than quantitative, and can be thought of (because individuals 
presumably use the numbers differently) as being measured with potentially large amounts of error.

The distribution of reported satisfaction levels for the sample of 5195 British employees in the BHPS data set is as follows. The sample excludes those who are self-employed, those who are retired, and those who are younger than 16. It includes part-time workers, and covers both the public and private sectors. The numbers are based on weighted data.

\begin{tabular}{ccc} 
Satisfaction level & Number of individuals & Percentage \\
\cline { 2 - 3 } 7 & 1645 & 31.7 \\
6 & 1396 & 26.9 \\
5 & 995 & 19.1 \\
3 & 654 & 12.6 \\
2 & 237 & 4.6 \\
1 & 90 & 1.7 \\
& 178 & 3.4 \\
\hline & - & 100.0
\end{tabular}

Almost a third of the sample give 7 as their answer to the question asking for their overall satisfaction with the job. This is the highest possible satisfaction category, so it appears that a significant proportion of employees are very happy with their work. For reported satisfaction levels 6 to 2, the frequency of response falls monotonically. As can be seen, 27\% of people give 6 as their answer; $19 \%$ say 5 ; and so on down to $2 \%$ giving their satisfaction rating as 2 . The lowest category of contentment with work, 1 , reveals an upturn in the frequency distribution to $3.4 \%$ of the sample.

To provide information about the correlations in the raw data, Table 1 describes satisfaction levels for different groups in the sample. The mean level of the satisfaction score is 
reported for each characteristic, as is the percentage who are 'highly satisfied' (reporting satisfaction of 6 or 7 on the 1-7 scale). The data demonstrate that men report themselves as noticeably less satisfied than women: the mean score for men is 5.3 while for women it is 5.7 , with the figures for the percentage highly satisfied being $52.9 \%$ and $65.0 \%$ respectively. Clark (1995b) explores this difference, which is significant at the 0.1 per cent level. Job satisfaction rises with the level of self-reported physical health. Individuals who work in small establishments are 'happier' than those in big establishments; union members are less happy than those who are nonunion. ${ }^{10}$ There is a strong effect from age, with some evidence of a mild U-shape, and a positive effect overall. Clark, Oswald and Warr (1995) investigate the possible causes of this age relationship. As an economist would predict, hours of work are negatively correlated with job satisfaction. Interestingly, and perhaps unexpectedly, the highly educated (with college degrees) are less satisfied than those with medium qualifications (A-Levels, O-Levels and nursing qualifications), who are in turn less satisfied than those with no or few qualifications (other).

A primary aim of the paper is to explore the idea that it is relative income, rather than absolute income, which gives utility. The bottom half of Table 1 provides cross-tabulations that begin to shed light on this issue. It reveals that absolute income, $y$, shows no sign of being positively correlated with job satisfaction. Contrary to what a microeconomics textbook would predict, employees earning in the lowest quintile of income report mean satisfaction of 5.92, with $70 \%$ reporting high job satisfaction, while those with income in the highest quintile report average satisfaction of 5.43, with 57\% reporting high job satisfaction. These are averages across a heterogeneous group, of course, and the presence of part-timers is particularly likely to confound the difficulty of drawing inferences. The last part of Table 1 moves to the male sub-sample, which should be more homogenous, and here the most satisfied individuals are, indeed, those in the highest income quintile. However, there is a U-shape in income, so again the results do not fit 
especially well with standard theoretical preconceptions. ${ }^{11}$

Finally, the influence of $y^{*}$ is examined. This is 'comparison income', which can be thought of as a reference level of income. ${ }^{12}$ The variable $y^{*}$ is calculated here by estimating a conventional earnings equation on the whole cross-section of employees, and then using this regression equation to predict an earnings level, $\mathrm{y}^{*}$, for each person. ${ }^{13}$ These $\mathrm{y}^{*}$ levels correspond to the income of 'typical' employees of given characteristics. Someone denoted k, for example, with a college degree, working in metal manufacturing, living in London, of age 45, and in a particular occupation (and with a set of other particular characteristics), is assumed to have a predicted income, $\mathrm{y}_{\mathrm{k}}$, which he or she knows is the going rate of pay for someone like him or her. One hypothesis is that the utility of person $\mathrm{k}$ depends on the gap between $\mathrm{y}_{\mathrm{k}}$ and $\mathrm{y}_{\mathrm{k}}$.

Counter to the spirit of the normal economics textbook, satisfaction is, according to Table 1 , more strongly correlated with relative income than absolute income. Here the variable is the ratio $\mathrm{y} / \mathrm{y}^{*}$. The denominator, $\mathrm{y}^{*}$, which might be denoted 'comparison income', is the income that a typical person of given characteristics would receive. For men, for example, Table 1 reveals that average satisfaction in the lowest quintile of relative income is 5.06, whereas in the highest quintile of relative income it is 5.39. Moving through the relative-income quintiles, mean satisfaction scores for men are respectively: 5.06, 5.27, 5.21, 5.40, and 5.39. Higher relative income seems to bring well-being. ${ }^{14}$

A more systematic analysis of satisfaction data begins in Table 2. Here, and throughout the remainder of the section, the method of estimation is by ordered probit (see Zavoina and McKelvey, 1975). This allows the efficient use of ordered qualitative data such as satisfaction scores. Broadly similar findings can be produced by following the less satisfactory method adopted in most of the psychology literature, that is, by averaging the ordinal responses to all eight of the satisfaction questions asked and estimating OLS equations. 
Column 1 of Table 2 estimates a simple form of textbook utility function. It assumes that well-being depends on the level of income and the number of hours worked. The central prediction of conventional microeconomic theory is rejected: income enters with a negative rather than positive sign. Hours of work, however, do enter in the theoretically expected negative way. Psychology textbooks appear to omit this influence from discussions of job satisfaction, so this empirical result may not be well-known in that literature. Column 1 of Table 2 also reveals that there is a strongly significant U-shaped relationship between job satisfaction and age (see Clark, Oswald and Warr, 1995) and that men say that they are less satisfied, ceteris paribus, than women. The equation also incorporates dummies for region, industry, occupation, health and race.

Column 2 of Table 2 provides a statistical test of the hypothesis that worker satisfaction depends on relative rather than absolute income. It uses a comparison income variable derived by predicting the typical income of someone with the individual's observable characteristics. ${ }^{15}$ Comparison income enters negatively and significantly. Its coefficient is -0.2 (with a standard error of 0.06) in column 2 of Table 2. Income is positive, with a coefficient of 0.11 , and significant at the 5 per cent level in column $2 .{ }^{16}$ The Chi-squared statistic at the foot of the Table shows that, for this specification, the restriction that $\mathrm{y}$ and $\mathrm{y}^{*}$ have equal and opposite signs is not rejected by the data. The hours of work variable is negative, on the border of significance. Because the coefficients on income and hours are approximately equal and opposite, the satisfaction equation look a little like an indirect utility function dependent on hourly income. The age variables continue to show a U-shaped relationship with job satisfaction; the male dummy is negative and significant.

The income measure used in these analyses is gross monthly income. However, the progressivity of the tax system might bias downwards the estimates on the income variables. As a test, the same method of analysis was repeated using after-tax income. The results were 
essentially unchanged, with predicted net income being negative and strongly significant in a job satisfaction equation, and net income itself being positive and significant.

An objection to the formulation used so far is that $\mathrm{y}^{*}$, the comparison level of pay, is derived within the data set. The difference between $y$ and $\mathrm{y}^{*}$ is a residual from an earnings regression equation, so the significance of this residual in a satisfaction equation might simply reflect mis-specification. On this view, column 2 of Table 2 might be seen as a form of Hausman test with no implications for the theory that relative deprivation matters. To check this, an alternative version was estimated. Column 3 of Table 2 uses as its measure of $y^{*}$ a set of income levels drawn from an external data source. The 1991 New Earnings Survey provides data on the earnings of workers of different kinds. Employees' length of usual basic working week was divided into 28 categories both for males and for females. Each individual in the BHPS was then assigned the $\mathrm{y}^{*}$ level corresponding to his or her usual basic weekly hours of work. This method produced 56 data points for comparison income. Each is an income cell-mean by gender and weekly hours.

Column 3 of Table 2 uses these $y^{*}$ data. In column 3 the coefficient on comparison income is -0.26 with a t-statistic in excess of 3 . By comparison, column 2 of Table 2, based on the previous method for calculating $\mathrm{y}^{*}$, had a well-defined coefficient of -0.20 . The similarity suggests that the role played by $\mathrm{y}^{*}$ is not the result of a mis-specification (in the Hausman-test style). ${ }^{17}$

Table 3 sets out a more general specification, and checks the previous results using a second type of satisfaction measure: satisfaction with pay. Columns 1 and 2, which refer to overall job satisfaction and satisfaction with pay respectively, include both the earlier variables and also extra dummy variables for second job, renter, temporary contract, managerial status and incentive payments. For completeness, Table 3 also leaves in the $\mathrm{Mu}$ terms denoting the 
estimated thresholds which define the estimated probabilities of reporting different satisfaction scores. There was no strong sign of an effect of unionism on overall job satisfaction, as studied in Freeman (1978), Borjas (1979), Meng (1990) and Miller (1990). The main conclusion is that, even in this general specification, comparison income has a negative and significant effect upon workers' reported levels of satisfaction. ${ }^{18}$

Comparison-wage effects are quantitatively important as well as statistically significant. The mean of $\mathrm{y}^{*}$ is 6.5 and its standard deviation is 0.8. A move from one standard deviation below the mean of $y^{*}$ to one standard deviation above is therefore a change from 5.7 to 7.3 . Taking a conservative central estimate of $y^{*}$ 's coefficient to be -0.2 , the implied change in the (latent) satisfaction variable is approximately -0.3 points. Given the distribution of satisfaction, this is a large effect. It is greater than the consequences of switching gender; it is equal to the difference between an average 25 year-old and an average 55 year-old; it greatly exceeds the dissatisfaction from not having a supervisory job.

These results appear to offer statistical credence to the hypothesis that feelings of wellbeing depend on a reference or comparison level of income. By contrast, they provide little support for the simple view, presented in microeconomics textbooks, that a worker's level of wellbeing is a function of absolute income.

\section{Satisfaction and Education}

A related result is presented in Table 4. It looks at the relationship between satisfaction and education (after controlling for income). Table 4 contains two ordered probits, in each of which three dummies for educational attainment are included as well as a control for income. The dummies are for a college degree, advanced high school (A-level approximately), and intermediate high school (O-level approximately). The omitted category is for no or low qualifications. These four categories are for achieved paper certificates and not merely for years of schooling. The first 
column in Table 4 pertains to overall job satisfaction and the second column to satisfaction with pay. Counter to what neoclassical economic theory might lead one to expect, highly educated people appear less content. The effect is monotonic and well-defined. Although the correlation between pay satisfaction and education disappears when income is not controlled for, that between overall job satisfaction and education stays. A specification of column 1 of Table 4 without the income variables yielded almost exactly the same results. That is not easy to interpret and is probably best viewed cautiously.

One potential explanation of the education finding that does not rely on aspirations is the recession which hit the middle class unexpectedly hard in Britain in the early 1990's. The low satisfaction of the higher educated might then just result from their sharp drop in income relative to those with lower qualifications. The results in Clark (1995c) suggest that, when entered jointly, both income one year ago and education are strongly negatively correlated with current job satisfaction, implying that both comparisons with past earnings and education are important predictors of job satisfaction.

A further check was done. If the education result is robust, it should have been noted before by researchers in the psychology literature. A search of the literature, and discussions with Michael Argyle and Peter Warr, suggested that, although not part of orthodox thinking, there is some supporting statistical evidence. Klein and Maher (1966), for example, show that education is significant and negative after controlling for occupational level. In Warr (1992), education enters negatively and significantly both with and without a large set of control variables. Watson et al (1992) find, for a small sample of managers, that educational qualifications are negative, with a t-statistic of approximately unity, in a job satisfaction equation. They also find a significant effect from wage relative to comparison wage, which may absorb some of their education coefficient. Borjas (1979) obtains no significant education effects, but his satisfaction question 
may have been interpreted by respondents as referring narrowly to job content. Results in Blanchflower and Oswald (1992), using the National Child Development Study, suggest that those with college degrees are the least satisfied with their work. Finally, Hagenaars (1986, chapter 10) shows that, in a multi-country study, those with a higher level of education need higher levels of income to attain certain verbal levels of well-being (such as "excellent" or "good").

\section{Conclusion}

This paper is an attempt to test the hypothesis that happiness depends on income relative to a 'comparison' or reference level. It produces two findings. First, workers' reported satisfaction levels are shown to be negatively related, in ordered probits, to their comparison earnings levels. Second, it is established that, holding income constant, satisfaction is declining in the level of education. This may be because education induces higher aspirations, but (as a referee has pointed out) there is no guarantee that this is the right interpretation. More generally, the paper indicates the potential - still untapped by economists - of reported satisfaction statistics as proxy utility data.

Despite what economics textbooks say, comparisons in the utility function seem to matter. This has a number of implications. In a world with comparisons, the case for growth as a way of increasing happiness is no longer so clear (see Easterlin, 1974 and Layard, 1980). Optimal tax policies are affected, because there are negative externalities from high earners (see Oswald, 1983). In an analogous way, the wages offered by firms may have low variance if there are intrafirm comparison effects, and may rise over time if workers compare their current wage to their own previous wages (see Frank and Hutchens, 1993). Moreover, because preferences are intrinsically interdependent, the standard optimality results of the free market may fail to hold. 


\section{$\underline{\text { Footnotes }}$}

* For their helpful comments about the literature, we thank Michael Argyle, James Banks, Ian Baxter, Dan Hamermesh and Peter Warr. Barry McCormick also kindly discussed with us his early unpublished work on GHS data, which preceded our own. Christoph Schmidt made especially good points to us. We have benefited from participants' comments in seminars at Aberdeen, Antwerp, Bristol, Cambridge, CEPREMAP, CREST, Dartmouth, DELTA, EMRU, Essex, the European Economic Association Congress (Maastricht), Exeter, Glasgow, INSEAD, the 11th Journées de Microéconomie Appliquée (Marseille), Laval, London School of Economics, the LSE Conference on the Economics and Psychology of Happiness and Fairness, Montreal, Munich, Newcastle, Oxford, Paris I, St Andrews and UCL. Special thanks are due to Alan Carruth, Andrew Chesher, Peter Dolton, Richard Freeman, Jonathan Gershuny, David Gray, Jonathan Haskel, Ross MacKay, Alan Manning, Costas Meghir, Pierre Picard, Tony Shorrocks, Steve Venti, Ian Walker and Frances Woolley. We are also grateful to Danny Blanchflower, Bob Elliot and Peter Sloane for helpful discussions and for examining results on different data sets. This research is primarily supported by the ESRC and the European Union. Part of this work was carried out while the first author was visiting CEPREMAP, Paris, whose hospitality is gratefully acknowledged. The data used in this paper were made available through the ESRC Data Archive. The data were originally collected by the ESRC Research Centre on Micro-social Change at the University of Essex. Neither the original collectors of the data nor the Archive bear any responsibility for the analyses or interpretations presented here.

1. The case for economic growth, for example, becomes less clear, and the case for progressive taxation stronger (Boskin and Sheshinski, 1978, and Oswald, 1983). Akerlof and Yellen (1990) argue that involuntary unemployment and other macroeconomic phenomena can also be explained this way.

2. For example, over long periods of time there is little upward movement in the mean reported level of happiness in sample surveys (Easterlin, 1974, and Argyle, 1989), and many writers argue on anecdotal grounds that our generation is no more content than earlier ones (Scitovsky, 1976, and Layard, 1980). Oswald (1994) reports modern European data showing approximately constant happiness levels over time. Recent US and British results are given in Blanchflower, Oswald and Warr (1993).

3. The term originates from Stouffer et al. (1949).

4. It might be argued, in the extreme, that these are random numbers merely made up by survey respondents. Psychologists, who are at least as aware of this possibility as economists, have long since abandoned such a view. See, for example, Chapter 9 of Argyle (1989).

5. The large literature includes Bernstein and Crosby (1980), Crosby (1976), Crosby and Gonzales-Intal (1984), Davis (1959), Festinger (1954), Lawler (1971), Maslow (1970), Pollis (1968), Pritchard (1969), Veenhoven (1991), Walster, Walster and Berscheid (1973) and Weik (1966).

6. Van de Stadt et al (1985), Stark and Taylor (1991) and Kosicki (1987) provide evidence for the relative income hypothesis. However, the indirect nature of the testing in the latter 
(studying savings decisions) leaves it open to many alternative interpretations. Brown and Sissons (1975) is consistent with relative deprivation theory, but also with the competitive model.

7. Hamermesh (1977) is a little hard to interpret. The author does not explain why he takes satisfaction to depend on the residual from an earnings equation rather than on earnings itself. He may believe that people use the word 'satisfaction' in an inherently relativistic way. His equations include only two other independent variables.

8. Factor analysis confirms this statement. A regression of overall job satisfaction on the first principal component of the seven individual job satisfaction questions yields a tstatistic on the latter of around 60, with a $\chi^{2}$-statistic of over 3000 . Job satisfaction regressions with the first principal component as the dependent variable produce results very similar to those with overall job satisfaction reported later in the paper.

9. The approach taken in this paper assumes that interpersonal comparisons of utility are meaningful. Harsanyi (1987) comments that "economists and philosophers influenced by logical positivism have greatly exaggerated the difficulties we face in making interpersonal utility comparisons with respect to the utilities and disutilities that people derive from ordinary commodities and, more generally, from the ordinary pleasures and calamities of human life" (p.957). See also Van Praag (1991) and Tinbergen (1991).

10. These results are known in the psychology literature. Weaver (1980) is a useful reference paper.

11. Calculating these means for full-time workers only did not substantially change the results.

12. The most famous problem with Adam's $(1963,1965)$ equity theory is that of knowing how to calculate comparison income (and comparison 'inputs' such as effort and education), such information being very rarely contained in surveys (Melenberg, 1992, is an exception). This paper uses an economic model to predict the wage against which the individual compares his own.

13. Arguably it is close co-workers' wages that matter most to an individual (as Frank, 1985, suggests), but that cannot easily be explored with these data.

14. This cannot be interpreted as the individual simply suffering from having a bad 'match' in a job at worse pay than elsewhere. In conventional economic theory, individuals do not suffer from regret. Their utility depends on their achieved wage.

15. The appendix reports the earnings equation used to calculate comparison income, $\mathrm{y}^{*}$, for each individual. It has a conventional structure, so is given in compressed form. The equation has many more explanatory variables than the satisfaction equation. There are two reasons for this. First, the control variables in the satisfaction equation were chosen to be as close to exogenous as possible. Second, the long list of additional variables entering the earnings equation might be thought of as identifying the satisfaction equation. As is common in applied microeconomics, this identifying assumption - which, more strictly, is in this case a way to avoid the perfect multi-collinearity that would result from 
including on the right hand side of the satisfaction equation both income and all the statistical determinants of income - is open to objections. A pragmatic counter-argument is that the results in Tables such as 2 or 3 are robust to wide variations in the choice of variables omitted from the satisfaction equations.

16. Most regressions have the counter-intuitive implication that a ten percent rise in both $y$ and $y^{*}$ would leave an individual worse off. There are four potential explanations of this weak effect. First, there could be an omitted variable, say 'effort', which is positively correlated with income and negatively correlated with job satisfaction, leading to a downward bias on the income estimate. However, such a bias should also apply to the coefficient on $\mathrm{y}^{*}$, unless it is assumed that individuals compare income only and not effort. Alternatively, the omitted variable could be education, which the second part of this paper shows to be strongly negatively correlated with job satisfaction. However, specifications with $y, y^{*}$ and education (see Clark, 1995b) produce negative significant estimates on the latter two variables, with the estimate on income remaining positive and insignificant. A second, related, explanation follows from Frank's idea that, because comparisons between coworkers are important, a market for local status develops. In this market, workers with high status subsidise the wages of low status workers. In this model, status, which is unobservable in our dataset, is thus negatively correlated with income and positively correlated with job satisfaction. A standard omitted variables argument then shows that the estimated income coefficient is biased downwards. Third, if there is measurement error in income then $\mathrm{y}^{*}$, because it is always a kind of average, will be less subject to error than y. Last, some recent work on utility functions (Frank and Hutchens, 1993, and Kahneman, 1993) has suggested that it may not be the level of variables which is important but rather their rate of change, implying that the change in y should predict utility better than the level of y. Clark (1995c) finds evidence of this effect (see also Gardes and Combris, 1994).

17. The same comparison income variable, determined by banded hours and gender, may also be calculated from within the BHPS dataset. If the regression results in column 3 of Table 2 are similar to those with a 'NES type' measure of $y^{*}$ from within the BHPS then this provides some evidence against the Hausman interpretation of the previous regressions. In fact the 'NES type' $y *$ attracts an estimate of -0.22 with a standard error of 0.07 . This is similar to the estimate of -0.26 for the NES numbers themselves reported in Table 2.

18. New results from the BHPS dataset supporting comparison income theory are presented in Clark (1995c), Clark et al (1994) and Clark (1995a). The first two show that the employee's wage one year ago is negatively correlated with current job satisfaction. The coefficients on current wage and wage one year ago have almost equal and opposite signs, suggesting that overall job satisfaction is a function of the change in income, rather than its level. In the latter article, some evidence is found of a negative correlation between an individual's job satisfaction and the income of other workers in the household, especially that of the spouse.

\section{APPENDIX. LOG GROSS MONTHLY INCOME EQUATION}


Age 20-29

0.49

$(16.62)$

Age 30-39

0.56

$(16.76)$

Age 40-49

0.56

$(15.80)$

Age 50-59

0.53

(13.91)

Age 60+

0.37

(7.71)

Male

0.18

(8.82)

Health dummies (5)

Yes

Regional dummies (18)

Yes

Occupation dummies (77)

Yes

Industry dummies (61)

Yes

Education dummies (12)

Yes

Accident dummies (3)

When work dummies (9)

Establishment size dummies (11)

Sex mix at work dummies (5)

Organization type dummies(7)

Marriage dummies (5)

Temporary contract

Yes

Yes

Yes

Yes

Yes

Yes

$-0.23$

(9.00)

0.07

(4.50)

$-0.74$

(33.3)

Union member

0.07

(3.46)

Trade Union recognised

0.04

(2.04)

Supervisor

0.16

(9.57)

Pension member

0.13

(7.10)

Job tenure

$-4.2 \mathrm{E}-06$

(0.56)

Job tenure squared

$3.2 \mathrm{E}-10$

$(0.44)$

Constant

5.61

(48.16)

Number of observations

4582

Adjusted R ${ }^{2}$

0.77

(t-statistics in parentheses) 


\section{REFERENCES}

Adams, J.S., 1963, Toward an Understanding of Inequity, Journal of Social Psychology 67, 422436.

Adams, J.S., 1965, Inequity in Social Exchange, in: L.Berkowitz, ed., Advances in Experimental Social Psychology, 2 (Academic Press, New York and London).

Akerlof, G.A., A.K. Rose and J.L. Yellen, 1988, Job Switching and Job Satisfaction in the U.S. Labor Market, Brookings Papers on Economic Activity 2, 495-582.

Akerlof, G.A. and J.L. Yellen, 1990, The Fair Wage - Effort Hypothesis and Unemployment, Quarterly Journal of Economics 105, 255-284.

Argyle, M., 1989, The Social Psychology of Work, 2nd edn. (Penguin Press, Harmondsworth).

Bartel, A.P., 1981, Race Differences in Job Satisfaction: A Reappraisal, Journal of Human Resources 16, 295-303.

Baxter, J.L., 1988, Social and Psychological Foundations of Economic Analysis (Harvester Wheatsheaf, New York).

Bernstein, M. and F.J. Crosby, 1980, An Empirical Examination of Relative Deprivation Theory, Journal of Experimental Social Psychology 16, 442-456.

Blanchflower, D.G. and A.J. Oswald, 1992, Entrepreneurship, Happiness and Supernormal Returns: Evidence from Britain and the US, NBER Working Paper 4228, Cambridge, Mass.

Blanchflower, D.G., A.J. Oswald and P.B. Warr, 1993, Well-Being over Time in Britain and the USA, London School of Economics, mimeo.

Bolton, G., 1991, A Comparative Model of Bargaining: Theory and Evidence, American Economic Review 81, 1096-1136.

Borjas, G.J., 1979, Job Satisfaction, Wages and Unions, Journal of Human Resources 14, 21-40.

Boskin, M. and E. Sheshinski, 1978, Optimal Redistributive Taxation When Individual Welfare Depends Upon Relative Income, Quarterly Journal of Economics 92, 589-601.

Bradburn, N. and D. Caplovitz, 1965, Reports on Happiness (Aldine, Chicago).

Bradburn, N. and C.E Noll, 1969, The Structure of Psychological Well-Being (Aldine, Chicago). Brown, W. and K. Sissons, 1975, The Use of Comparisons in Workplace Wage Determination, British Journal of Industrial Relations 13, 25-53.

Cappelli, P. and K. Chauvin,1991, An Inter-Plant Test of the Efficiency Wage Hypothesis, Quarterly Journal of Economics 106, 769-787.

Cappelli, P. and P.D. Sherer, 1988, Satisfaction, Market Wages and Labour Relations: An Airline Study, Industrial Relations 27, 56-73.

Clark, A.E., 1995a, Is Utility Relative? Evidence From Household Data, DELTA, mimeo.

Clark, A.E., 1995b, Job Satisfaction and Gender: Why are Women so Happy at Work?, DELTA, Discussion Paper no.95-10.

Clark, A.E., 1995c, Wages, Raises and Job Satisfaction: Evidence for a Relative Utility Function, DELTA, mimeo.

Clark, A.E., 1996, Job Satisfaction in Britain, British Journal of Industrial Relations, forthcoming.

Clark, A.E., S. Dex, K. Perren, D. Rose and M. Taylor, 1994, Changes in Economic Activity, in: N.Buck, J.Gershuny, D.Rose and J.Scott, eds., Changing Households (ESRC Research Centre Press, Colchester).

Clark, A.E. and A.J. Oswald, 1994a, Unhappiness and Unemployment, Economic Journal 104, 648-659. 
Clark, A.E. and A.J. Oswald, 1994b, Following Behaviour in Social and Economic Settings, London School of Economics, mimeo.

Clark, A.E., A.J. Oswald and Warr, P.B., 1995, Is Job Satisfaction U-shaped In Age?, Journal of Occupational and Organizational Psychology, forthcoming.

Clegg, C.W., 1983, Psychology of Employee Lateness, Absence and Turnover: A Methodological Critique and an Empirical Study, Journal of Applied Psychology 68, 88-101.

Crosby, F.J., 1976, A Model of Egoistical Relative Deprivation, Psychological Review 83, 85113.

Crosby, F.J. and A.M. Gonzales-Intal, 1984, Relative Deprivation and Equity Theories: Felt Injustice and the Undeserved Benefits of Others, in: R.Folger, ed., The Sense of Injustice (Plenum Press, New York).

Davis, J.A., 1959, A Formal Interpretation of the Theory of Relative Deprivation, Sociometry 22, 280-296.

Deaton, A., 1992, Understanding Consumption (Oxford University Press, Oxford and New York).

Duesenberry, J.S., 1949, Income, Saving and the Theory of Consumer Behaviour (Harvard University Press, Cambridge, Mass.).

Easterlin, R., 1974, Does Economic Growth Improve the Human Lot? in P.A.David and W.B. Melvin, eds., Nations and Households in Economic Growth (Stanford University Press, Palo Alto).

Festinger, L., 1954, A Theory of Social Comparison Processes, Human Relations 7, 117-140.

Frank, R.H., 1984a, Are Workers Paid Their Marginal Products?, American Economic Review $74,549-571$.

Frank, R.H., 1984b, Interdependent Preferences and the Competitive Wage Structure, Rand Journal of Economics 15, 510-520.

Frank, R.H., 1985, Choosing the Right Pond: Human Behaviour and the Quest for Status (Oxford University Press, London and New York).

Frank, R.H. and R.M. Hutchens, 1993, Wages, Seniority, and the Demand for Rising Consumption Profiles, Journal of Economic Behaviour and Organization 21, 251-276.

Freeman, R.B., 1978, Job Satisfaction as an Economic Variable, American Economic Review 68, 135-141.

Gardes, F. and P. Combris, 1994, The Increasing Marginal Utility of Relative Income: Empirical Findings on French Individual Data, CREDOC Cahier de Recherche No.62.

Guth, W., R. Schmittberger and B. Schwarz, 1982, An Experimental Analysis of Ultimatum Bargaining, Journal of Economic Behaviour and Organization 3, 367-388.

Gylfason, T. and A. Lindbeck, 1984, Union Rivalry and Wages: An Ologopolistic Approach, Economica 51, 129-139.

Hagenaars, A.J., 1986, The Perception of Poverty (North-Holland, Amsterdam).

Hamermesh, D.S., 1977, Economic Aspects of Job Satisfaction, in: O.C.Ashenfelter and W.E.Oates, eds., Essays in Labor Market Analysis (John Wiley, New York).

Harsanyi, J.C., 1986, Interpersonal Utility Comparisons, in J.Eatwell, M.Milgate and P.Newman, eds., The New Palgrave Dictionary of Economics (Macmillan, London).

Hochman, H.M. and J.D. Rogers, 1969, Pareto Optimal Redistribution, American Economic Review 59, 542-557.

Homans, G.C., 1961, Social Behaviour: Its Elementary Forms (Harcourt Brace, New York). 
Idson, T.L., 1990, Establishment Size, Job Satisfaction and the Structure of Work, Applied Economics 22, 1007-1018.

Ireland, N.J., 1994, On Limiting the Market for Status Signals, Journal of Public Economics 53, 91-110.

Johansen, K. and B. Strøm, 1994, Efficiency Wages, Interfirm Comparison and Unemployment, University of Trondheim, mimeo.

Kahneman, D., J.L. Knetsch and R. Thaler, 1986, Fairness as a Constraint on Profit Seeking: Fairness in the Market, American Economic Review 76, 728-741.

Kahneman, D., 1993, New Challenges to the Rationality Assumption, Princeton University, mimeo.

Kapteyn, A. and F.G. Van Herwaarden, 1980, Interdependent Welfare Functions and Optimal Income Distribution, Journal of Public Economics 14, 375-397.

Klein, S.M. and J.R. Maher, 1966, Education Level and Satisfaction with Pay, Personnel Psychology 19, 195-208.

Kosicki, G., 1987, A Test of the Relative Income Hypothesis, Southern Economic Journal 54, 422-434.

Lawler, E.E., 1971, Pay and Organizational Effectiveness: A Psychological View (McGraw Hill, New York).

Layard, R., 1980, Human Satisfactions and Public Policy, Economic Journal 90, 737-750.

Lévy-Garboua, L. and C. Montmarquette, 1994, On Reported Job Satisfaction: A Test of Subjective Well-Being Models and a New Interpretation, Université Paris I, mimeo.

Locke, E.A., 1976, The Nature and Causes of Job Satisfaction, in M.D. Dunnette, ed., Handbook of Industrial and Organizational Psychology (Rand-McNally, Chicago).

Lommerud, K.E., 1989, Educational Subsidies When Relative Income Matters, Oxford Economic Papers 41, 640-652.

Long, J.M., J.J. Lynch, N.M. Machiran, S.A. Thomas and K. Malinow, 1982, The Effect of Status on Blood Pressure During Verbal Communication, Journal of Behavioural Medicine $5,165-171$.

Mangione, T.W. and R.P. Quinn, 1975, Job Satisfaction, Counter-Productive Behaviour and Drug Use at Work, Journal of Applied Psychology 60, 114-116.

Maslow, A.H., 1970, Motivation and Personality (Harper and Row, New York).

McEvoy, G.M. and W.F. Cascio, 1985, Strategies for Reducing Employee Turnover: A Meta Analysis, Journal of Applied Psychology 70, 342-353.

Melenberg, B., 1992, Micro-econometric Models of Consumer Behaviour and Welfare, Tilburg University, mimeo.

Meng, R., 1990, The Relationship Between Unions and Job Satisfaction, Applied Economics 22, 1635-1648.

Miller, P., 1990, Trade Unions and Job Satisfaction, Australian Economic Papers 29, 226-248.

Nickell, S.J. and M. Andrews, 1983, Trade Unions, Real Wages and Employment in Britain 195179, Oxford Economic Papers 35, 507-530.

Oswald, A.J., 1979, Wage Determination in an Economy with Many Trade Unions, Oxford Economic Papers 31, 369-385.

Oswald, A.J., 1983, Altruism, Jealousy and the Theory of Optimal Non-Linear Taxation, Journal of Public Economics 20, 77-87.

Oswald, A.J., 1994, Happiness and Economic Performance, London School of Economics, mimeo. 
Palmore, E., 1969, Predicting Longevity: A Follow-Up Controlling for Age, Journal of Gerontology 39, 109-116.

Pencavel, J., 1991, Labour Markets Under Trade Unionism: Employment, Wages and Hours (Basil Blackwell, Oxford).

Pollis, N.P., 1968, Reference Group Re-examined, British Journal of Sociology 19, 300-307.

van Praag, B.M., 1991, Ordinal and Cardinal Utility, Journal of Econometrics 50, 69-89.

Pritchard, R.D., 1969, Equity Theory: A Review and Critique, Organizational Behaviour and Human Performance 4, 176-211.

Runciman, W.G., 1966, Relative Deprivation and Social Justice (Routledge and Kegan Paul, Henley).

Sales, S.M. and J. House, 1971, Job Dissatisfaction as a Possible Risk Factor in Coronary Heart Disease, Journal of Chronic Diseases 23, 861-873.

Sen, A.K., 1983, Poor, Relatively Speaking?, Oxford Economic Papers 35, 153-169.

Scitovsky, T., 1976, The Joyless Economy (Oxford University Press, New York).

Sloane, P.J. and H. Williams, 1994, Job Satisfaction, Comparison Income, and Gender Differences in Earnings, University of Aberdeen, mimeo.

Smith, V.L., 1994, Economics in the Laboratory, Journal of Economic Perspectives 8, 113-132.

Solow, R.M., 1990, The Labor Market as a Social Institution (Basil Blackwell, Oxford).

Stark, O. and J.E. Taylor, 1991, Migration Incentives, Migration Types: The Role of Relative Deprivation, Economic Journal 101, 1163-1178.

Stouffer, S.A. et al., 1949, The American Soldier (Princeton University Press, Princeton).

Tinbergen, J., 1991, On the Measurement of Welfare, Journal of Econometrics 50, 7-15.

Trevithick, J.A., 1976, Money Wage Inflexibility and the Keynesian Labour Supply Function, Economic Journal 86, 327-332.

Van de Stadt, H., A. Kapteyn and S. Van de Geer, 1985, The Relativity of Utility: Evidence from Panel Data, Review of Economics and Statistics 67, 179-187.

Veblen, T., 1949, The Theory of the Leisure Class (George Allen and Unwin, London). Originally published 1899 by Macmillan, New York.

Veenhoven, R., 1991, Is Happiness Relative?, Social Indicators Research 24, 1-34.

Wall, T.D., C.W. Clegg and P.R. Jackson, 1978, An Evaluation of the Job Characteristics Model, Journal of Occupational Psychology 51, 183-196.

Walster, E., G.W. Walster and E. Berscheid, 1973, New Directions in Equity Research, Journal of Personality and Social Psychology 25, 151-176.

Warr, P., ed., 1985, Psychology at Work (Penguin Press, Harmondsworth).

Warr, P., 1992, Age and Occupational Well-Being, Psychology and Aging 7, 37-45.

Watson, R., D. Storey, P. Wynarczyk, K. Keasey and H. Short, 1992, An Empirical Analysis of the Salaries and Satisfaction Levels of Managers in Small and Medium-Size UK Enterprises, Warwick Business School, mimeo.

Weaver, C.N., 1980, Job Satisfaction in the United States in the 1970s, Journal of Applied Psychology 65, 364-367.

Weik, K.E., 1966, The Concept of Equity in the Perception of Pay, Administrative Science Quarterly 11, 414-439.

Wood, A., 1978, A Theory of Pay (Cambridge University Press, Cambridge).

Zavoina, R. and W. McKelvey, 1975, A Statistical Model for the Analysis of Ordinal-Level Dependent Variables, Journal of Mathematical Sociology 4, 103-120. 


\section{TABLE 1. MEAN REPORTED JOB SATISFACTION LEVELS}

\begin{tabular}{|c|c|c|}
\hline OVERALL & $5.50(.021)$ & $\begin{array}{l}\text { \% of individuals reporting } \\
\text { themselves very satisfied } \\
58.7(0.69)\end{array}$ \\
\hline $\begin{array}{l}\text { Male } \\
\text { Female }\end{array}$ & $\begin{array}{l}5.31(.030) \\
5.71(.029)\end{array}$ & $\begin{array}{l}52.9(0.99) \\
65.0(0.94)\end{array}$ \\
\hline $\begin{array}{l}16-19 \\
20-29 \\
30-39 \\
40-49 \\
50-59 \\
60+\end{array}$ & $\begin{array}{l}5.55(.072) \\
5.32(.044) \\
5.40(.043) \\
5.50(.042) \\
5.72(.057) \\
6.16(.086)\end{array}$ & $\begin{array}{l}59.1(2.49) \\
53.4(1.40) \\
56.1(1.38) \\
58.6(1.39) \\
66.3(1.79) \\
75.9(2.86)\end{array}$ \\
\hline $\begin{array}{l}\text { Health-excellent } \\
\text { Health-good } \\
\text { Health-other }\end{array}$ & $\begin{array}{l}5.68(.035) \\
5.47(.030) \\
5.25(.055)\end{array}$ & $\begin{array}{l}65.0(1.15) \\
57.3(0.99) \\
50.9(1.62)\end{array}$ \\
\hline $\begin{array}{l}\text { Education-higher } \\
\text { Education-A/O/Nursing } \\
\text { Education-other }\end{array}$ & $\begin{array}{l}5.38(.039) \\
5.44(.033) \\
5.67(.038)\end{array}$ & $\begin{array}{l}55.8(1.33) \\
57.1(1.09) \\
62.9(1.18)\end{array}$ \\
\hline $\begin{array}{l}<16 \text { hours p.w. } \\
16-29 \text { hours p.w. } \\
\text { 30-39 hours p.w. } \\
\geq 40 \text { hours p.w. }\end{array}$ & $\begin{array}{l}5.93(.057) \\
5.84(.057) \\
5.36(.030) \\
5.41(.043)\end{array}$ & $\begin{array}{l}70.0(1.91) \\
68.3(1.85) \\
54.5(0.98) \\
56.3(1.40)\end{array}$ \\
\hline $\begin{array}{l}\text { Monthly pay: lowest quintile } \\
\text { Monthly pay: second quintile } \\
\text { Monthly pay: third quintile } \\
\text { Monthly pay: fourth quintile } \\
\text { Monthly pay: highest quintile }\end{array}$ & $\begin{array}{l}5.92(.047) \\
5.48(.053) \\
5.32(.054) \\
5.34(.049) \\
5.43(.045)\end{array}$ & $\begin{array}{l}70.0(1.52) \\
58.8(1.62) \\
54.8(1.64) \\
53.2(1.65) \\
57.0(1.63)\end{array}$ \\
\hline $\begin{array}{l}\text { y/y*: lowest quintile } \\
\mathrm{y} / \mathrm{y}^{*}: \text { second quintile } \\
\mathrm{y} / \mathrm{y} *: \text { third quintile } \\
\mathrm{y} / \mathrm{y}^{*}: \text { fourth quintile } \\
\mathrm{y} / \mathrm{y}^{*}: \text { highest quintile }\end{array}$ & $\begin{array}{r}5.39(.057) \\
5.37(.053) \\
5.41(.054) \\
5.57(.048) \\
5.54(.052)\end{array}$ & $\begin{array}{l}56.2(1.74) \\
54.9(1.74) \\
57.1(1.73) \\
58.0(1.73) \\
61.5(1.70)\end{array}$ \\
\hline $\begin{array}{l}\text { Men } \\
\text { Monthly pay: lowest quintile } \\
\text { Monthly pay: second quintile } \\
\text { Monthly pay: third quintile } \\
\text { Monthly pay: fourth quintile } \\
\text { Monthly pay: highest quintile }\end{array}$ & $\begin{array}{l}5.36(.075) \\
5.08(.081) \\
5.25(.073) \\
5.26(.070) \\
5.53(.059)\end{array}$ & $\begin{array}{l}53.8(2.37) \\
47.6(2.33) \\
50.9(2.34) \\
51.1(2.36) \\
60.8(2.28)\end{array}$ \\
\hline $\begin{array}{l}\text { y/y*: lowest quintile } \\
\text { y/y*: second quintile } \\
\text { y/y*: third quintile } \\
\text { y/y*: fourth quintile } \\
\text { y/y*: highest quintile }\end{array}$ & $\begin{array}{r}5.06(.082) \\
5.27(.071) \\
5.21(.077) \\
5.40(.071) \\
5.39(.073)\end{array}$ & $\begin{array}{l}46.2(2.45) \\
50.7(2.45) \\
52.8(2.45) \\
54.3(2.45) \\
56.1(2.43)\end{array}$ \\
\hline
\end{tabular}

Notes: As explained in the text, these data refer to a cross-section of approximately five thousand British workers in 1991. 'Very satisfied' denotes job satisfaction of 6 or 7 on the 1-7 scale. The F-statistic for the equality of means was significant at the 5\% level in every case bar one (relative pay and the percentage highly satisfied). Standard errors are in parentheses. All figures refer to weighted data. 


\begin{tabular}{|c|c|c|c|}
\hline Log income $(y)$ & $\begin{array}{l}-0.02 \\
(0.039)\end{array}$ & $\begin{array}{l}0.11 \\
(0.050)\end{array}$ & $\begin{array}{l}-0.001 \\
(0.04)\end{array}$ \\
\hline Log comparison income $\left(\mathrm{y}^{*}\right)$ & --- & $\begin{array}{l}-0.20 \\
(0.062)\end{array}$ & --- \\
\hline Log NES comparison income $\left(\mathrm{y}^{* *}\right)$ & --- & --- & $\begin{array}{l}-0.26 \\
(0.073)\end{array}$ \\
\hline Log hours (h) & $\begin{array}{l}-0.15 \\
(0.054)\end{array}$ & $\begin{array}{l}-0.12 \\
(0.065)\end{array}$ & $\begin{array}{l}0.09 \\
(0.09)\end{array}$ \\
\hline Age & $\begin{array}{l}-0.029 \\
(0.008)\end{array}$ & $\begin{array}{l}-0.016 \\
(0.010)\end{array}$ & $\begin{array}{l}-0.031 \\
(0.009)\end{array}$ \\
\hline Age-squared/1000 & $\begin{array}{l}0.51 \\
(0.11)\end{array}$ & $\begin{array}{l}0.34 \\
(0.12)\end{array}$ & $\begin{array}{l}0.53 \\
(0.11)\end{array}$ \\
\hline Male & $\begin{array}{l}-0.24 \\
(0.040)\end{array}$ & $\begin{array}{l}-0.22 \\
(0.045)\end{array}$ & $\begin{array}{l}-0.16 \\
(0.05)\end{array}$ \\
\hline Regional dummies (18) & Yes & Yes & Yes \\
\hline Industry dummies (10) & Yes & Yes & Yes \\
\hline Occupation dummies (9) & Yes & Yes & Yes \\
\hline Health dummies (3) & Yes & Yes & Yes \\
\hline Race dummies (3) & Yes & Yes & Yes \\
\hline Number of observations & 4506 & 4039 & 4506 \\
\hline Log-likelihood & -7112.7 & -6416.3 & -7106.6 \\
\hline Log-likelihood at zero & -7312.0 & -6595.9 & -7312.0 \\
\hline $\begin{array}{l}\text { Chi-squared (1) statistic for the test } \\
\text { that } \mathrm{y}^{*} \mathrm{y}^{*}=0 \text { or } \mathrm{y}+\mathrm{y}^{* *}=0 \text { : }\end{array}$ & --- & 2.8 & 10.8 \\
\hline
\end{tabular}

Note: NES comparison income $\mathrm{y}^{* *}$ is drawn from the 1991 New Earnings Survey. The $\mathrm{y}^{* *}$ levels are income cell-means by gender and by 28 categories for total usual weekly hours of work. Thus there are 56 data points for $\mathrm{y}^{* *}$. Standard errors are in parentheses. 


\section{Overall job satisfaction Satisfaction with pay}

\begin{tabular}{|c|c|c|}
\hline Log income (y) & $\begin{array}{l}0.12 \\
(0.051)\end{array}$ & $\begin{array}{l}0.77 \\
(0.051)\end{array}$ \\
\hline Log comparison income $\left(\mathrm{y}^{*}\right)$ & $\begin{array}{l}-0.26 \\
(0.061)\end{array}$ & $\begin{array}{l}-0.31 \\
(0.062)\end{array}$ \\
\hline Male & $\begin{array}{l}-0.18 \\
(0.043)\end{array}$ & $\begin{array}{l}-0.25 \\
(0.045)\end{array}$ \\
\hline Age & $\begin{array}{l}-0.017 \\
(0.009)\end{array}$ & $\begin{array}{l}-0.037 \\
(0.009)\end{array}$ \\
\hline Age-squared/1000 & $\begin{array}{l}0.34 \\
(0.12)\end{array}$ & $\begin{array}{l}0.54 \\
(0.12)\end{array}$ \\
\hline Region dummies & Yes & Yes \\
\hline Log hours & $\begin{array}{l}-0.14 \\
(0.063)\end{array}$ & $\begin{array}{l}-0.86 \\
(0.065)\end{array}$ \\
\hline Health dummies & Yes & Yes \\
\hline Industry dummies & Yes & Yes \\
\hline Occupation dummies & --- & Yes \\
\hline Has second job & $\begin{array}{l}-0.14 \\
(0.057)\end{array}$ & --- \\
\hline Temporary contract & $\begin{array}{l}-0.26 \\
(0.069)\end{array}$ & --- \\
\hline Renter & $\begin{array}{l}0.15 \\
(0.043)\end{array}$ & $\begin{array}{l}0.09 \\
(0.043)\end{array}$ \\
\hline Manager/Supervisor & $\begin{array}{l}0.13 \\
(0.041)\end{array}$ & --- \\
\hline Incentive payments & --- & $\begin{array}{l}0.10 \\
(0.040)\end{array}$ \\
\hline $\mathrm{Mu}(1)$ & $\begin{array}{l}-3.66 \\
(0.27)\end{array}$ & $\begin{array}{l}-2.80 \\
(0.25)\end{array}$ \\
\hline $\operatorname{Mu}(2)$ & $\begin{array}{l}-3.46 \\
(0.27)\end{array}$ & $\begin{array}{l}-2.59 \\
(0.25)\end{array}$ \\
\hline $\operatorname{Mu}(3)$ & $\begin{array}{l}-3.10 \\
(0.27)\end{array}$ & $\begin{array}{l}-2.21 \\
(0.25)\end{array}$ \\
\hline $\mathrm{Mu}(4)$ & $\begin{array}{l}-2.53 \\
(0.27)\end{array}$ & $\begin{array}{l}-1.63 \\
(0.25)\end{array}$ \\
\hline $\operatorname{Mu}(5)$ & $\begin{array}{l}-1.95 \\
(0.27)\end{array}$ & $\begin{array}{l}-1.14 \\
(0.25)\end{array}$ \\
\hline $\mathrm{Mu}(6)$ & $\begin{array}{l}-1.19 \\
(0.27)\end{array}$ & $\begin{array}{l}-0.68 \\
(0.25)\end{array}$ \\
\hline Number of observations & 4031 & 4036 \\
\hline Log-likelihood & -6390.4 & -7509.8 \\
\hline Log-likelihood at zero & -6580.9 & -7544.1 \\
\hline $\begin{array}{l}\text { Chi-squared (1) statistic for the test } \\
\text { that } y+y^{*}=0 \text { : } \\
\text { (Standard errors in parentheses) }\end{array}$ & 6.7 & 65.3 \\
\hline
\end{tabular}




\section{Overall job satisfaction Satisfaction with pay}

\begin{tabular}{|c|c|c|}
\hline Log income & $\begin{array}{l}0.05 \\
(0.04)\end{array}$ & $\begin{array}{c}0.62 \\
(0.04)\end{array}$ \\
\hline College Degree & $\begin{array}{l}-0.65 \\
(0.08)\end{array}$ & $\begin{array}{l}-0.28 \\
(0.08)\end{array}$ \\
\hline $\begin{array}{l}\text { Advanced High School } \\
\text { (A-level) approximately }\end{array}$ & $\begin{array}{l}-0.39 \\
(0.05)\end{array}$ & $\begin{array}{l}-0.18 \\
(0.05)\end{array}$ \\
\hline $\begin{array}{l}\text { Intermediate High School } \\
\text { (O-level) approximately }\end{array}$ & $\begin{array}{l}-0.21 \\
(0.05)\end{array}$ & $\begin{array}{l}-0.09 \\
(0.05)\end{array}$ \\
\hline Log hours & $\begin{array}{l}-0.21 \\
(0.05)\end{array}$ & $\begin{array}{l}-0.91 \\
(0.05)\end{array}$ \\
\hline Age & $\begin{array}{l}-0.035 \\
(0.009)\end{array}$ & $\begin{array}{l}-.050 \\
(0.008)\end{array}$ \\
\hline Age-squared/1000 & $\begin{array}{l}0.54 \\
(0.11)\end{array}$ & $\begin{array}{l}0.69 \\
(0.11)\end{array}$ \\
\hline Male & $\begin{array}{l}-0.23 \\
(0.04)\end{array}$ & $\begin{array}{l}-0.28 \\
(0.04)\end{array}$ \\
\hline $\begin{array}{l}\text { Regional Dummies } \\
\text { Health dummies } \\
\text { Race dummies } \\
\text { Industry dummies } \\
\text { Occupation dummies }\end{array}$ & $\begin{array}{l}\text { Yes } \\
\text { Yes } \\
\text { Yes } \\
\text { Yes } \\
\text { Yes }\end{array}$ & $\begin{array}{l}\text { Yes } \\
\text { Yes } \\
\text { Yes } \\
\text { Yes } \\
\text { Yes }\end{array}$ \\
\hline $\begin{array}{l}\text { Number of observations } \\
\text { Log-likelihood } \\
\text { Log-likelihood at zero }\end{array}$ & $\begin{array}{l}4498 \\
-7062.1 \\
-7299.0\end{array}$ & $\begin{array}{l}4491 \\
-8160.8 \\
-8413.0\end{array}$ \\
\hline
\end{tabular}

(Standard errors in parentheses) 